IZA DP No. 6140

Does Migration Make You Happy?

A Longitudinal Study of Internal Migration and Subjective Well-Being

Beata Nowok

Maarten van Ham

Allan M. Findlay

Vernon Gayle

November 2011 


\title{
Does Migration Make You Happy? A Longitudinal Study of Internal Migration and Subjective Well-Being
}

\author{
Beata Nowok \\ University of St Andrews
}

Maarten van Ham

Delft University of Technology and IZA

\author{
Allan M. Findlay \\ University of St Andrews
}

\author{
Vernon Gayle \\ University of Stirling
}

\section{Discussion Paper No. 6140 \\ November 2011}

\author{
IZA \\ P.O. Box 7240 \\ 53072 Bonn \\ Germany \\ Phone: +49-228-3894-0 \\ Fax: +49-228-3894-180 \\ E-mail: iza@iza.org
}

\begin{abstract}
Any opinions expressed here are those of the author(s) and not those of IZA. Research published in this series may include views on policy, but the institute itself takes no institutional policy positions.

The Institute for the Study of Labor (IZA) in Bonn is a local and virtual international research center and a place of communication between science, politics and business. IZA is an independent nonprofit organization supported by Deutsche Post Foundation. The center is associated with the University of Bonn and offers a stimulating research environment through its international network, workshops and conferences, data service, project support, research visits and doctoral program. IZA engages in (i) original and internationally competitive research in all fields of labor economics, (ii) development of policy concepts, and (iii) dissemination of research results and concepts to the interested public.
\end{abstract}

IZA Discussion Papers often represent preliminary work and are circulated to encourage discussion. Citation of such a paper should account for its provisional character. A revised version may be available directly from the author. 


\section{ABSTRACT}

\section{Does Migration Make You Happy? A Longitudinal Study of Internal Migration and Subjective Well-Being}

The majority of modelling studies on consequences of internal migration focus almost exclusively on the labour market outcomes and the material well-being of migrants. We investigate whether individuals who migrate within the UK become happier after the move than they were before it and whether the effect is permanent or transient. Using life satisfaction responses from 12 waves of the British Household Panel Survey (BHPS) and employing a fixed-effects model, we derive a temporal pattern of migrants' subjective wellbeing (SWB) around the time of the migration event. Our findings make an original contribution by revealing for the first time that, on average, migration is preceded by a period when individuals experience a significant decline in happiness. The boost that is received through migration appears to bring people back to their initial level of happiness. As opposed to labour market outcomes of migration, SWB outcomes do not differ significantly between men and women. Perhaps surprisingly, long-distance migrants are at least as happy as short-distance migrants despite the higher social costs that are involved.

JEL Classification: J61, R23

Keywords: migration, happiness, subjective well-being, longitudinal data, UK

Corresponding author:

Beata Nowok

Centre for Population Change

School of Geography and Geosciences

University of St Andrews

KY16 9AL St Andrews, Fife

Scotland, UK

E-mail: beata.nowok@gmail.com 


\section{Introduction}

The study of internal migration has been predominately shaped by economic questions related to the labour market. At a micro-level, a decision to migrate is mainly explained by cost-benefit calculations leading to an expected positive net return, usually measured by monetary income. In other words, people are often assumed to maximize their utility expressed in pecuniary terms (Chiswick, 2008). The migration decision-making process at the family level is based on the evaluation of a joint return with potentially unequal gains or losses for spouses (Cooke, 2008). Much empirical evidence indicates that migration is beneficial for the careers of migrants, unless they are tied-movers (mostly women) who sacrifice their labour-market outcome for the sake of the net gain to the family as a whole.

Compared with the economic consequences of migration, much less is known about implications of migration for the general subjective well-being (SWB) of individuals. Whether migration brings happiness to all migrants is a crucial question, especially in the context of the growing interest in using well-being measures to evaluate societal progress. As is common in the literature, we use the terms SWB and happiness interchangeably. They refer to people's evaluations of their life which can be cognitive or affective (e.g. Diener, 2009; Diener et al, 2003). From a theoretical perspective, migration decision-making can still be encompassed within a utility-maximizing framework. Now, however, utility is captured by subjective judgments of satisfaction rather than monetary income.

A SWB framework for the analysis of migration has a number of advantages. It takes a wider perspective that incorporates the richness and diversity of current geographical mobility in terms of motivations and outcomes. People migrate for a variety of reasons, not only economic ones, but most expect to increase their quality of life and happiness through changing their place of residence. Migration is a stressful event requiring many adjustments (Magdol, 2002; McCollum, 1990) and therefore it has to offer the chance to gain something in return. Due to its complexity, migration affects many domains of the migrant life regardless of the motivations of move, and these effects can be either positive or negative. An outcome of migration on labour market does not have to coincide with the actual experience of the quality of life in a destination area, especially in the context of the illusory general belief that money brings happiness (Kahneman et al, 2006). Successful migration should, however, reach its goal and increase the migrants' subjective utility. We may expect negative effects of migration on SWB when a person moves involuntarily or when he or she mispredicts post-migration utility.

Evaluating migration results in terms of happiness rather than money has also substantial policy implications (Diener and Seligman, 2004). Policies designed to stimulate the economy by encouraging geographical mobility of households does not necessary lead to increased individual and overall societal well-being. General well-being has been recognized recently as a valuable measure to evaluate social progress and develop policy responses in France (Stiglitz et al, 2009) and in the UK (Prime Minister's Office, 25 November 2010; Stratton, 2010).

This study advances the idea of exploring the relationship between migration and SWB. We investigate whether individuals who migrate within the UK become happier after the move than they were before it. For those who report higher levels of happiness after migration, it is important to determine whether it is a permanent or transient effect. We use panel data and observe levels of SWB both prior and after migration events. To effectively follow happiness level of the same individuals over time we apply a fixed-effects panel data 
models. Additionally, we are interested in whether or not the effects are different for various types of migration.

The paper is structured as follows. Section 2 presents the background and previous literature. Section 3 describes the data and method used in the study. Section 4 presents the results of the empirical analysis. In Section 5 we present our conclusions.

\section{Background}

Set-point theory of SWB has been a prevailing paradigm in psychology (see Headey, 2010 for an overview; Lucas et al, 2003). The central premise is that individuals have stable levels of SWB given by genetics and personality. Deviations from the set-points may occur in the face of major life events, such as marriage, migration, unemployment, or serious injury, but their effects are usually transitory. There is, however, increasing evidence of lasting changes in individual happiness. Unemployment seems to be a reasonably common event which causes long-term decrease in set-points (Clark et al, 2008a; Lucas et al, 2004). Lucas et al. (2003) showed that marriage can have a long-lasting beneficial effect on SWB for some people. Easterlin (2006a) concluded in his review article that in family and health domains adaptation to changes is only partial, whereas people completely adapt to gains in the economic domain. Headey (2010) found large and permanent changes in SWB set-points for a large number of individuals participating in the German Socio-Economic Panel Survey (SOEP). He challenged the set-point theory and called for a substantial revision. Considering the emerging findings, it appears that happiness is shaped by both psychological factors and life circumstances (Easterlin, 2006b). It implies that people can play an active role in increasing their own happiness by making considered choices within their life strategies.

Migration can be seen as a means of potential lasting improvement in SWB. People migrate for various reasons but most expect to improve their lot in one way or another. They want to take advantage of opportunities available elsewhere. In terms of theoretical approach human capital or cost-benefit models predominate in the migration literature. People are assumed to behave rationally and move when the expected value of the benefits exceeds the costs (pecuniary and non-pecuniary). Thus migration should be beneficial for migrants. When more than one individual is involved in migration decision making, as in the case of family migration, a rational evaluation of the cost and benefits of moving are often more complex. Migration may be rational from the standpoint of the family as a whole, but not from the standpoint of each family member considered separately. Family migration may therefore provide disproportionate and unequal benefits to male and female partners (Coulter and van Ham, 2012; Mulder and Cooke, 2009).

The economic gains that are conventionally taken in the literature as a suitable measure of general migration outcome are one-sided and might be misleading. A key question is whether migration is effective in raising happiness, not least in the long-term. There are reasons to believe that this does not have to be the case. Migration is a move not only in physical, but also in social space. It is a multifaceted event involving shifts in many domains of life. An economically driven migration may be at considerable cost to social relationships. Moreover, spatial mobility is closely and complexly interrelated with family and career events which may not be neutral for SWB, e.g. divorce or loss of a job. An individuals' whole life satisfaction can be seen as an aggregate of satisfactions with the various domains of their life (Cummins, 1996; Schimmack, 2008; van Praag et al, 2003). However, the literature suggests that the weights assigned to various life domains may vary by individuals and also they may change over the individual's life span (McAdams et al, 2011; Pavot and Diener, in press). The studies adopting the life domain approach generally 
agree on domains that are central to determining happiness. They include economic conditions, family circumstances, health and work. All of these aspects of a person's life may be affected by a change of place of residence. Raising happiness in non-economic domains is, however, more effective than in economic ones (Easterlin, 2006a). The transient effect of income on life satisfaction is very often not realized by people (Kahneman et al, 2006).

As mentioned above, most research into the consequences of internal migration refers to objective outcomes in the economic domain. Outcomes differ substantially between lead and tied migrants. Women migrants are much more likely to be tied migrants than men (Mincer, 1978), even when the woman actually is the primary wage earner (Cooke, 2003), or has a higher ranking occupation than her partner (Boyle et al, 1999a). An extensive literature demonstrates that following family migration women's labour market status suffers in a number of ways (Boyle et al, 1999b; 2001; Halfacree, 1995; Lichter, 1983; Mincer, 1978). Women are less likely to be employed, have smaller incomes and work shorter hours than other equivalent women (Boyle et al, 2001; Cooke and Bailey, 1999; Morrison and Lichter, 1988; Shihadeh, 1991). Studies using longitudinal data found, however, that married women 'recover' to pre-migration income levels within one to three years after the move (Clark and Huang, 2006; LeClere and McLaughlin, 1997). The labour market outcome of migration is usually positive for men when they are lead migrants.

Success in economic domain does not imply, however, an increase in happiness, especially in the long term. The relation between income and happiness has attracted widespread attention, especially among economists and research results reveal intricate relationships (see e.g. Clark et al, 2008b; Easterlin, 1995; 2001; Easterlin et al, 2010; Ferreri-Carbonell, 2005; Kahneman et al, 2006; Stutzer, 2004). There is a weak effect of absolute income on SWB and several explanations emerge. First, in evaluating their financial situation people compare themselves to others. As a result relative income rather than absolute income is seen to affect happiness. Second, individuals adapt to material goods over time. People get used most easily to material possessions and very often they underestimate the process of habituation. Similarly, people's expectations adapt to their possibilities. Finally, higher income often shifts time-use towards activities associated with higher tension and stress. Wealthier people tend to devote relatively more time to work and commuting and less time to passive leisure activities (Kahneman et al, 2006).

The impact of other objective characteristics such as age, gender, marital status and education on happiness level is surprisingly very limited. The contradictory evidence existing in the literature prevents drawing firm conclusions for most of the examined correlates (for reviews see Diener, 2009; Diener and Seligman, 2004; Dolan et al, 2008). We highlight the influence of some selected migration-related characteristics. There is no significant difference between men and women when average levels of SWB are considered. Females are more likely, however, to report very high or very low levels of SWB. As regards age, many studies have found that SWB in adulthood can be characterized by a U-shaped curve with the lowest happiness occurring in middle age. A very useful overview of the relationship between wellbeing and age is presented by Blanchflower and Oswald (2008).

Happiness research emphasizes that individual evaluations of well-being go beyond economics. What is more important, raising happiness through material goods is almost certainly doomed in the long run. We expect, therefore, that assessment of a long-term return to migration in SWB terms will in most cases differ from calculations in monetary terms. An important question, which we aim to answer, is whether migration has a positive impact on individual long-term happiness level. Since happiness is considered by many as the ultimate goal in life, voluntary migration should facilitate this goal. People may, however, exaggerate the contribution of single factors to overall SWB, especially income. We expect also different consequences of migration by gender for at least two reasons. First, men and women tend to 
prioritize various domains of life that are affected differently by changing place of residence. Second, women are more likely to be trailing spouses. Being tied-movers may be, however, less harmful in SWB terms than in economic ones, since they may plausibly be less careeroriented. Finally, there is no doubt that SWB return to migration depends on its broadly defined type (short- versus long-distance migration).

\section{Data and methods}

\subsection{Migration and the British Household Panel Survey}

Panel data are especially beneficial in evaluation of the impact of migration as they allow a comparison of the situation before and after the event. For this study we use the British Household Panel Survey (BHPS), for the years 1996-2008 (this is the final year of the original panel). In 1996 the questions on overall life satisfaction were introduced. The BHPS is a nationally representative sample of approximately 5,500 private households with approximately 10,000 adults recruited in 1991. The adult members (aged over 15) of the same sample of households are interviewed every year. The following rules of the BHPS lead to new households being included in the survey. The BHPS was also augmented by regional geographical samples. Therefore in 2008 the total sample size was around 9,000 households including some 15,000 individuals. The BHPS attempts to follow up all migrants who remain in Great Britain. Although, as expected, attrition among migrants is higher than among nonmigrants, its extent is relatively small and does not pose a problem for the analysis of geographical mobility (Buck, 2000; Rabe and Taylor, 2010).

The migration behaviour of the BHPS respondents can be tracked using two different indicators provided in the dataset. Panel members are directly asked whether they still live at the same residence as before 1 September of the previous year. In the case of change of residence, information on month and year of the move is collected. The BHPS also provides a derived individual mover status variable indicating whether sample members have moved location since last interview. We identify migration events combining the information contained in both variables. Migration is broadly defined as a change in the usual place of residence (address) between two consecutive interviews. This includes both local and longdistance moves. A migrant is a person who undertakes migration at least once during the complete observation period (1996-2008). Depending on the number of migrations he or she experiences we distinguish one-time migrants and multiple migrants. Our data indicate that, on average, about $11 \%$ of people migrate every year. This adds up to a total of more than 20,500 migration events in the years 1996-2008. Around 38\% of the migrating individuals change place of residence more than once over the observation period. As a result there are 12,000 migrants in the dataset. It is common in migration research for analysts to consider only the first move rather than all moves. The first migration observed in the dataset is not necessarily the first migration experienced in the respondent's life. Therefore, a focus on first moves only would to some extent be artificial.

On average an individual moves a distance of $32 \mathrm{~km}$. Nonetheless, half of moves are of distance shorter than $3.2 \mathrm{~km}$. About $9 \%$ of all moves are motivated by reasons related to respondent's job. The share of job-related migrations increases with distance $-31 \%$ for distance exceeding $25 \mathrm{~km}$ as opposed to $3 \%$ below this threshold. The number of migrations experienced by heterosexual couples (both married and cohabiting) equals about 3,600. Approximately $11 \%$ of those couples migrate for reasons associated with job of either or both partners. Half of the job-related moves of the couples are associated with only man's job, while around $20 \%$ with only woman's job. 
The SWB measure is derived by the evaluation question: 'How dissatisfied or satisfied are you with your life overall?' There are seven possible response options ranging from 'not satisfied at all' to 'completely satisfied'. A neutral point of the scale is 4 at which respondents report that they are neither satisfied nor dissatisfied. Despite its simplicity, this single-item measure appears to be a fairly robust indicator of SWB and is frequently employed in the literature. It is also used as a dependant variable in this study.

\subsection{Modelling approach}

Our objective is to examine how SWB changes relative to the time of migration. To account for individual differences and effectively track the same people over time we apply a fixedeffects model ${ }^{1}$. In order to capture the time path of SWB we create a series of dummy duration variables. They represent the number of years before or after the occurrence of a migration event. The resulting regression equation takes the form:

$$
\mathrm{SWB}_{i t}=\alpha_{i}+\beta \mathbf{X}_{i t}+\sum_{k=-\mathrm{T}_{1}}^{\mathrm{T}_{2}} \theta_{k} \mathrm{M}_{i t}^{k}+\varepsilon_{i t},
$$

where $\mathrm{SWB}_{i t}$ denotes the subjective well-being of individual $i$ in period $t$. The individual fixed effect, $\alpha_{i}$, controls for any time-constant unobserved heterogeneity. $\mathbf{X}_{i t}$ is a vector of time-varying covariates. It includes a set of individual and household characteristics that are common in the literature on SWB. In particular, we consider age, marital status, labour market status and self-assessed health at an individual level and birth of a child, number of children and income at the household level. The dummy variables, $\mathrm{M}_{i t}^{k}$, indicate if a person $i$ migrates in period $t-k$, with $k$ indexing the variables beginning $\mathrm{T}_{1}$ years before and ending $\mathrm{T}_{2}$ years after migration. The last group refers to all years beyond $\mathrm{T}_{2}$. For instance, $\mathrm{M}_{i t}^{3}=1$ if an individual $i$ migrated three years before year $t$. In other words, at year $t$ he or she has been living in a new place of residence for three years. If $\mathrm{M}_{i t}^{-3}=1$, it indicates that a person $i$ will migrate from a current place of residence in three years. The parameters $\theta_{k}$ measure therefore the impact of migration prior to $(k<-1)$ and following the move $(k \geq 0)$. Finally, $\varepsilon_{i t}$ is a stochastic error term, indexed $i$ for the individual and $t$ for time.

A similar modelling approach was adopted for examining life satisfaction effects of major life events by Clark et al. (2008a) and Frijters et al. (2011). In economic literature analogous models are used to evaluate earnings losses of displaced workers (Couch, 2001; Couch et al, 2011; Couch and Placzek, 2010; Jacobson and LaLonde, 1993; White, 2010).

Given the nature of the dependant variable (seven ordered outcomes) an ordered response regression might seem more appropriate. There are two main reasons in favour of a linear model. First, linear analysis is superior in its ease of interpretation. Second, the analysis of SWB carried out by the two models leads to similar substantive results (Clark et al, 2008a; Ferrer-i-Carbonell and Frijters, 2004).

\section{Results}

\subsection{Empirical regularities in SWB and migration}

Our data confirm that most people are reasonably happy (Diener and Diener, 1996). Around $76 \%$ of the BHPS respondents indicate SWB above neutral. The SWB metric records an average level of happiness of 5.23 and there is no significant difference between men and

\footnotetext{
${ }^{1}$ We have also estimated the model in a random-effects framework and formally compared the models using the Hausman test. The results favour a fixed-effects specification.
} 
women. Migrants are, on average, significantly less happy than non-migrants. Migrants are defined as in Section 3 and thus the aggregate measures for them are derived from all available observations prior to and after migration(s). The average SWB scores for migrants and non-migrants are respectively 5.16 and 5.30. Multiple migrants are again unhappier (5.12) than one-time migrants (5.20).

SWB and migration exhibit strong regularities in age profiles (Figure 1). Happiness tends to be approximately U-shaped over the adult life cycle with the minimum occurring in middle age. The most prominent regularity in the age schedule of migration is the high concentration of migration among young adults. The differences in aggregate measures of happiness between migrants and non-migrants may, therefore, reflect a compositional effect of age. The empirical age profiles of migration and SWB of both migrants and non-migrants (together and separately) are set out in Figure 1.

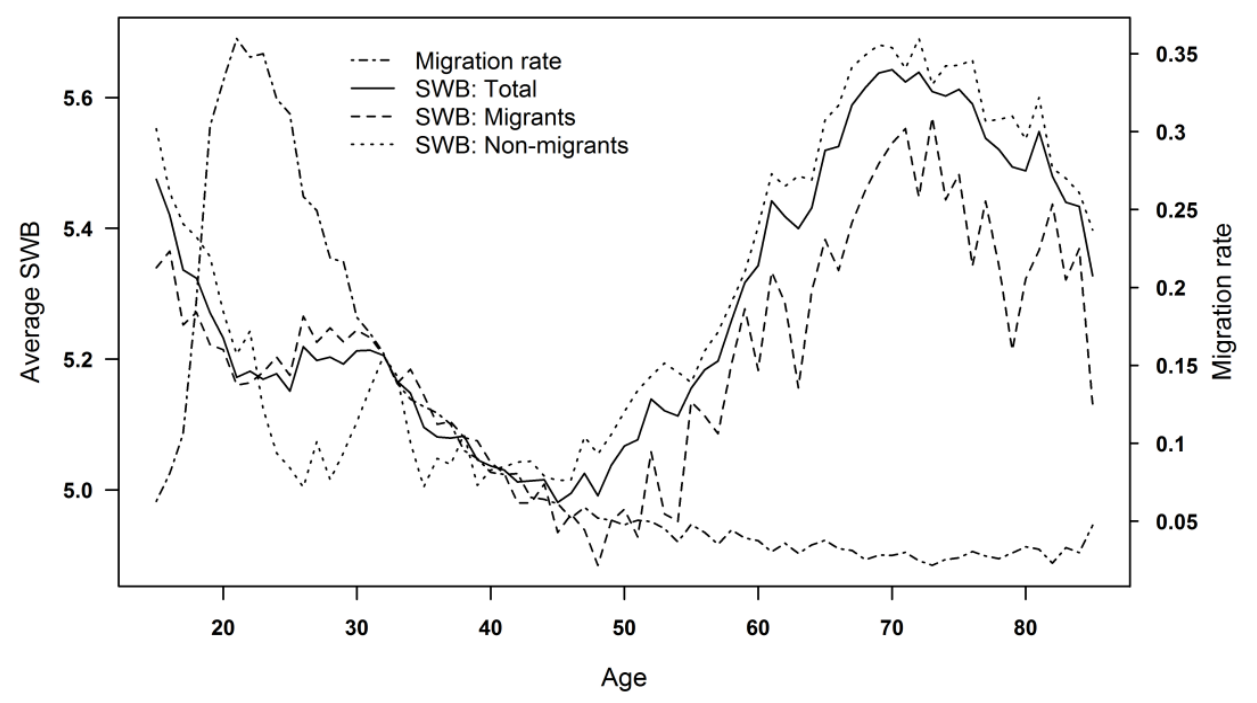

Figure 1 Average subjective well-being (SWB) and migration rate by age, 1996-2008

We can make a few observations based on the presented age schedules and the relationship between them. The average SWB of the total population starts high in young adulthood, reaches the minimum at age 45 , then rises substantially to age 70 and starts to decline thereafter. Most migration events are concentrated between ages 18-30. Non-migrants are happier that non-migrants at all ages except between 23 and 40 years. The higher SWB of migrants at most mobile ages, which drives the happiness of the whole population, especially at ages 23-30, suggest a positive impact of changing place of residence, at least in short term. An increase in SWB for migrants may be also attributed to the relationship of age to some aspects of the family life-cycle and the resulting motives for migration, e.g. marriage. In order to understand the impact of migration on SWB, it is therefore of importance to follow the same individuals over time, and control for other life events and personal characteristics.

Before we move on to the analysis of the long-term dynamics of SWB, we present what we can learn from comparison of male and female happiness before and after migration depending on distance and reason for the move (values can be consulted in Table 1). The available data do not allow estimating long-term SWB patterns in small subgroups making such descriptive analysis even more informative. At the first interview following migration event the respondents' average SWB is 5.15, which is higher by 0.05 than that at the interview preceding the move. Distance itself has a limited impact on the happiness level reported after the change of place of residence. Nonetheless, migrants who move a distance 
of 25-50 km become happier after migration. As expected, reasons for moving influence the migration outcome. In general, migrants motivated by job issues are happier than those migrating for other reasons regardless of the migration distance.

Table 1 Post-migration subjective well-being (SWB) by reason, gender and distance.

\begin{tabular}{|c|c|c|c|c|c|c|c|c|}
\hline \multirow{2}{*}{$\begin{array}{l}\text { Reason for } \\
\text { migration }\end{array}$} & \multirow{2}{*}{ Gender } & \multicolumn{7}{|c|}{ Distance in kilometres } \\
\hline & & $0-5$ & $5-10$ & $10-25$ & $25-50$ & $50-100$ & $100-200$ & $200+$ \\
\hline Total & Total & $\begin{array}{c}5.15 \\
(0.05)^{\mathrm{a}}\end{array}$ & $\begin{array}{c}5.12 \\
(0.05)\end{array}$ & $\begin{array}{c}5.15 \\
(0.11)\end{array}$ & $\begin{array}{c}5.23 \\
(0.16)\end{array}$ & $\begin{array}{c}5.22 \\
(-0.02)\end{array}$ & $\begin{array}{c}5.13 \\
(-0.02)\end{array}$ & $\begin{array}{c}5.15 \\
(0.13)\end{array}$ \\
\hline \multirow{2}{*}{ Job } & Male & $\begin{array}{c}5.22 \\
(0.16)\end{array}$ & $\begin{array}{c}5.23 \\
(0.37)\end{array}$ & $\begin{array}{c}5.27 \\
(0.39)\end{array}$ & $\begin{array}{c}5.34 \\
(0.25)\end{array}$ & $\begin{array}{c}5.31 \\
(0.21)\end{array}$ & $\begin{array}{c}5.21 \\
(0.16)\end{array}$ & $\begin{array}{c}5.21 \\
(0.15)\end{array}$ \\
\hline & Female & $\begin{array}{c}5.36 \\
(0.23)\end{array}$ & $\begin{array}{c}5.33 \\
(0.44)\end{array}$ & $\begin{array}{c}5.15 \\
(0.10)\end{array}$ & $\begin{array}{c}5.29 \\
(0.27)\end{array}$ & $\begin{array}{c}5.25 \\
(0.00)\end{array}$ & $\begin{array}{l}5.18 \\
(0.06)\end{array}$ & $\begin{array}{c}5.17 \\
(0.19)\end{array}$ \\
\hline \multirow{2}{*}{$\begin{array}{l}\text { Other } \\
\text { reasons }\end{array}$} & Male & $\begin{array}{c}5.14 \\
(0.01)\end{array}$ & $\begin{array}{l}5.15 \\
(0.02)\end{array}$ & $\begin{array}{c}5.12 \\
(0.10)\end{array}$ & $\begin{array}{c}5.16 \\
(0.23)\end{array}$ & $\begin{array}{c}5.15 \\
(-0.05)\end{array}$ & $\begin{array}{c}5.04 \\
(-0.13)\end{array}$ & $\begin{array}{c}5.12 \\
(0.24)\end{array}$ \\
\hline & Female & $\begin{array}{c}5.16 \\
(0.08)\end{array}$ & $\begin{array}{l}5.08 \\
(0.04)\end{array}$ & $\begin{array}{c}5.18 \\
(0.11)\end{array}$ & $\begin{array}{c}5.27 \\
(0.06)\end{array}$ & $\begin{array}{c}5.18 \\
(-0.09)\end{array}$ & $\begin{array}{c}5.03 \\
(0.00)\end{array}$ & $\begin{array}{c}5.03 \\
(0.08)\end{array}$ \\
\hline
\end{tabular}

Notes: ${ }^{\text {a }}$ in parentheses change compared to pre-migration SWB.

The SWB of males and females does not differ considerably. There are, however, some remarkable discrepancies between the happiness of partners, both married and cohabiting, migrating together (Table 2). Men become happier only when migration is related to their own job. It is even more rewarding when spouse's job plays a role as a motivating factor as well. The post-migration SWB of women migrating with partners remains practically the same as it was before the move, regardless of migration reason. They are relatively happy and being tied migrant is not really harmful for them.

Table 2 Post-migration subjective well-being (SWB) of partners in migrating couples ${ }^{\text {a }}$

\begin{tabular}{lccc}
\hline $\begin{array}{l}\text { Reason for } \\
\text { migration }\end{array}$ & $\begin{array}{c}\text { No. of migrations } \\
\text { by couples }\end{array}$ & Male & Female \\
\hline Man's job & 218 & $5.35(0.12)^{\mathrm{b}}$ & $5.35(-0.03)$ \\
Woman's job & 96 & $5.07(-0.06)$ & $5.30(0.00)$ \\
Both partners' jobs & 133 & $5.39(0.18)$ & $5.27(0.03)$ \\
Other reason & 2841 & $5.21(-0.01)$ & $5.28(0.01)$ \\
\hline
\end{tabular}

Notes: ${ }^{\mathrm{a}}$ couples include both married and cohabiting partners; ${ }^{\mathrm{b}}$ in parentheses change compared to pre-migration SWB.

\subsection{Dynamic effect of migration on $S W B$}

The examined period when migration is assumed to affect happiness spreads over nine years. It begins four years prior to the year when a person reports a move and ends five years after that year. The coefficient $\theta_{-5}$ is, therefore, fixed and equal to zero (see Equation (1) in Section 3). The estimated dynamic effect of migration on SWB for the full sample and for men and women separately is illustrated in Figure 2. Here and in the following figures the vertical line at zero indicates migration but, to be precise, time zero is the time of interview. Inevitably the interview occurred after the migration event. Thus the migration act took place at an unspecified time between minus one and zero on the graph. Detailed regression results are presented in Table 3. 


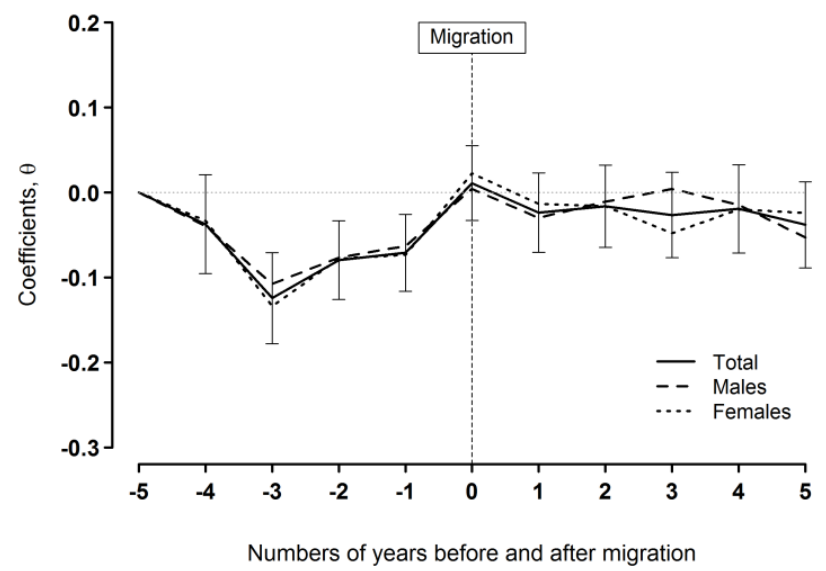

Figure 2 The dynamic effect of migration on subjective well-being (SWB) for total, males and females.

Notes: Error bars indicate $95 \%$ confidence intervals for total.

For the full sample, the coefficients on the migration-related dummies are all negative except for the year of migration (Figure 2 and the first ten rows of Table 3). The SWB drops to a level significantly lower than zero three years before the change of residence and remains significantly negative till the year preceding the change. The first important finding of the research is that migration boosts migrants' happiness relative to people's feelings of wellbeing before moving. More precisely, migration seems to take away negative feelings or unhappiness, but as Figure 2 shows the upward shift in subjective well-being does not continue in the years after migration. In the year of migration the SWB seems to have returned to its original level and stagnates thereafter. This pattern would be compatible with an interpretation of migration taking place as a result of some stressor. Moving to overcoming the stressor is therefore a positive action, but it should not be interpreted in bringing any extra happiness or improved well-being relative to the migrant's status before the stressor took effect. Table 3 shows that the coefficients for the years after migration are not significant. The interpretation of the findings as presented above would uphold research on the 'immobility paradox' (Fischer and Malmberg, 2001) that notes that most people do not move unless they have to, even when the measurable gains that mobility might offer are selfevident. By contrast some people move because of unacceptable stress in one or more domains of their lives reducing well-being to unacceptable levels. A final feature of Table 3 that seems worthy of note in relation to the coefficients relating to SWB in years before and after migration is that the research would seem to substantiate the view that it is circumstances at a time well before migration that may be critical in bringing about the decision to move, and that the search process for a new location that satisfies the potential movers concerns may take some time to find - hence the three year lag between the low point on the SWB graph and the time of migration.

As regards the effects of the other variables on SWB, the results confirm a strong relationship between SWB and self-assessed health and a large negative impact of unemployment, which are usually found in the literature. Being married or living as a couple appears to increase SWB. Being separated or widowed is associated with the lowest level of happiness. Moreover, there is a positive effect of household income on the SWB of its members. 
Table 3 Fixed-effects model of subjective well-being; the coefficient estimates for the whole sample

\begin{tabular}{|c|c|c|c|c|c|c|}
\hline \multirow{2}{*}{$\begin{array}{l}\text { Variable }^{\text {a }} \\
\text { No. of years before and after } \\
\text { migration }\end{array}$} & \multicolumn{2}{|c|}{ Total } & \multicolumn{2}{|c|}{ Males } & \multicolumn{2}{|c|}{ Females } \\
\hline & & & & & & \\
\hline-4 & -0.037 & $(0.030)^{\mathrm{b}}$ & -0.039 & $(0.042)$ & -0.033 & $(0.041)$ \\
\hline-3 & $-0.124^{* * *}$ & $(0.027)$ & $-0.108^{* * *}$ & $(0.039)$ & $-0.134^{* * *}$ & $(0.038)$ \\
\hline-2 & $-0.079^{* * *}$ & $(0.024)$ & $-0.077^{* *}$ & $(0.034)$ & $-0.078^{* *}$ & $(0.033)$ \\
\hline-1 & $-0.071^{* * *}$ & $(0.023)$ & $-0.063^{*}$ & $(0.033)$ & $-0.073^{* *}$ & $(0.032)$ \\
\hline 0 & 0.011 & $(0.023)$ & 0.004 & $(0.032)$ & 0.023 & $(0.031)$ \\
\hline 1 & -0.024 & $(0.024)$ & -0.030 & $(0.034)$ & -0.013 & $(0.033)$ \\
\hline 2 & -0.016 & $(0.025)$ & -0.011 & $(0.035)$ & -0.016 & $(0.034)$ \\
\hline 3 & -0.027 & $(0.026)$ & 0.004 & $(0.036)$ & -0.048 & $(0.036)$ \\
\hline 4 & -0.019 & $(0.027)$ & -0.014 & $(0.038)$ & -0.020 & $(0.037)$ \\
\hline 5 & -0.038 & $(0.026)$ & -0.053 & $(0.037)$ & -0.024 & $(0.036)$ \\
\hline Age & $-0.007^{* * *}$ & $(0.003)$ & $-0.019^{* * *}$ & $(0.004)$ & 0.002 & $(0.004)$ \\
\hline Age squared/100 & -0.001 & $(0.002)$ & $0.011^{* * *}$ & $(0.004)$ & $-0.011^{* * *}$ & $(0.003)$ \\
\hline \multicolumn{7}{|l|}{ Marital status } \\
\hline Married / living as couple & $0.128^{* * *}$ & $(0.017)$ & $0.118^{* * *}$ & $(0.025)$ & $0.136^{* * *}$ & $(0.024)$ \\
\hline Widowed & $-0.210^{* * *}$ & $(0.031)$ & $-0.144^{* * *}$ & $(0.051)$ & $-0.230^{* * *}$ & $(0.041)$ \\
\hline Divorced & $-0.081^{* * *}$ & $(0.028)$ & $-0.141^{* * *}$ & $(0.044)$ & -0.042 & $(0.038)$ \\
\hline Separated & $-0.282^{* * *}$ & $(0.031)$ & $-0.395^{* * *}$ & $(0.048)$ & $-0.206^{* * *}$ & $(0.042)$ \\
\hline \multicolumn{7}{|l|}{ Labour market status } \\
\hline Unemployed & $-0.305^{* * *}$ & $(0.017)$ & $-0.334^{* * *}$ & $(0.023)$ & $-0.278^{* * *}$ & $(0.026)$ \\
\hline Student & $0.110^{* * *}$ & $(0.018)$ & $0.126^{* * *}$ & $(0.026)$ & $0.102^{* * *}$ & $(0.024)$ \\
\hline Long term sick, disabled & $-0.371^{* * *}$ & $(0.021)$ & $-0.448^{* * *}$ & $(0.030)$ & $-0.308^{* * *}$ & $(0.028)$ \\
\hline Child born this year & $0.077^{* * *}$ & $(0.015)$ & 0.030 & $(0.022)$ & $0.115^{* * *}$ & $(0.021)$ \\
\hline Number of children & $-0.010^{*}$ & $(0.006)$ & 0.007 & $(0.008)$ & $-0.027^{* * *}$ & $(0.008)$ \\
\hline Equivalized household income ${ }^{c}$ & $0.012^{* * *}$ & $(0.002)$ & $0.017^{* * *}$ & $(0.003)$ & $0.009^{* * *}$ & $(0.003)$ \\
\hline \multicolumn{7}{|l|}{ Health status over last 12 months } \\
\hline Excellent & $0.369^{* * *}$ & $(0.010)$ & $0.363^{* * *}$ & $(0.015)$ & $0.375^{* * *}$ & $(0.015)$ \\
\hline Good & $0.233^{* * *}$ & $(0.008)$ & $0.240^{* * *}$ & $(0.011)$ & $0.226^{* * *}$ & $(0.011)$ \\
\hline Poor & $-0.281^{* * *}$ & $(0.012)$ & $-0.296^{* * *}$ & $(0.019)$ & $-0.273^{* * *}$ & $(0.016)$ \\
\hline Very poor & $-0.645^{* * *}$ & $(0.022)$ & $-0.718^{* * *}$ & $(0.036)$ & $-0.604^{* * *}$ & $(0.029)$ \\
\hline
\end{tabular}

Notes: ${ }^{\text {a }}$ coefficients on wave dummies are not reported; reference categories are never married and fair health; ${ }^{\mathrm{b}}$ standard errors in parentheses; ${ }^{c}$ in thousand pounds; ${ }^{*}$ significant at $10 \%,{ }^{* * *}$ significant at $5 \%,{ }^{* * *}$ significant at $1 \%$.

There are no substantial gender differences in the impact of migration on SWB. Similarly the research showed that females migrating in couples experience similar SWB trends as their partners, although these results are not presented here. Given the literature on the labour market consequences of migration, which indicate that migration is harmful for females, this finding runs counter to the expectations. Women, who are tied migrants more often than men, do not seem to sacrifice their happiness while losing their career opportunities. It may suggest that women attach lower importance to work than men. It should also be noted that men's happiness appears not to be affected either by the birth of a child or the number of children in the household.

The great diversity of population mobility means that it would be desirable to undertake an analysis disaggregating movers by their self-defined motivations for migration as well as by types of move in terms of distance and household type. An elaborate division of 
migration events into subgroups would lead, however, to seriously limited sample sizes. Thus we restrict the analysis here to just a broad categorisation of movement types. We distinguish local moves from distant moves with a threshold set at $25 \mathrm{~km}$ (dominated by moves for housing and personal reasons and excluding longer distance moves that tend to be rather different in nature often being associated with labour market switchers as well as migration for educational purposes, especially the migration of students from their parental home to study at universities). This threshold also approximates to the significant divide recognised in migration studies between moves that permit the mover to maintain social ties with most of their former social network and longer distance moves that require the migrant to form new social bonds. On this basis one might anticipate that short distance movers would be happier than longer distance movers simply because they experience less social costs in moving, since their social network is not disrupted to the same extent.

Figure 3 plots changes in the SWB around the time of the migration event estimated separately for long- and short-distance moves. Curiously, and counter to the hypothesis established above about mobility, well-being and the breaking of social networks, longdistance migrants seem to be happier in general than the short-distance movers. Moreover, the positive effect of migration is observed for a longer period (two years after move) before it starts to wear off. The sample size for longer distance migrants is small, however, and so some caution is required to limit reading too much into trends for this group. We focus, therefore, on residential mobility only. The coefficients and the standard errors for the model estimated for men and women together and separately are presented in Table 4. Figure 3 and Figure 4 illustrates the general shape of changes in SWB as a function of short-distance migration for the same groups.

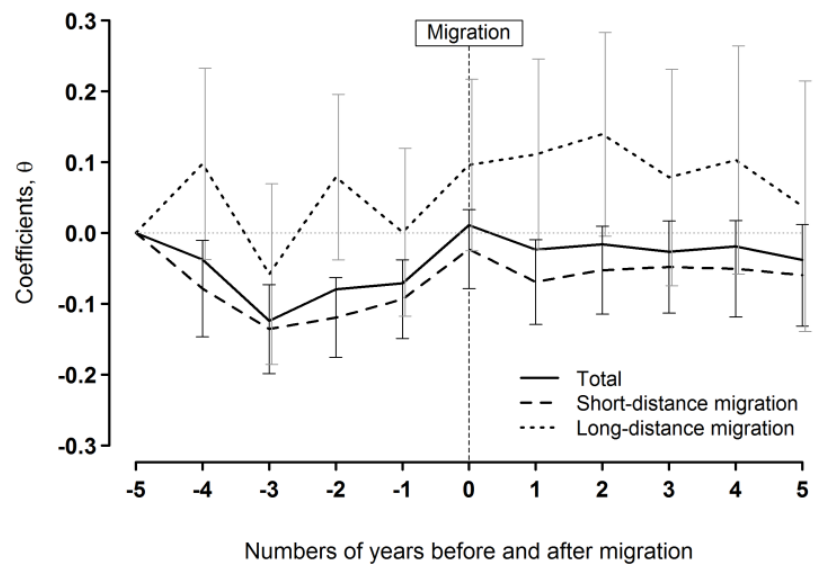

Figure 3 The dynamic effect of short- and long-distance migration on subjective well-being (SWB)

Notes: Error bars indicate $95 \%$ confidence intervals for short- and long-distance migrations.

Interestingly, local moves take place after a relatively bigger decline in SWB and movers do not recover to their initial level of well being after their move although, as with Figure 2, the SWB graph stagnates in the years after the move has taken place. The effect of migration distance is driven by changes in happiness experienced by men. In the case of women, its impact is negligible. Again, it suggests that relative importance of life domains in determining general life satisfaction differs between genders. Males get lower satisfaction from changes related to residential mobility. Migration to a distant place that usually offers them more career opportunities and a chance to begin a new life appears to be more effective in boosting their happiness, but as Figure 3 shows, this effect is not quite statistically significant. 

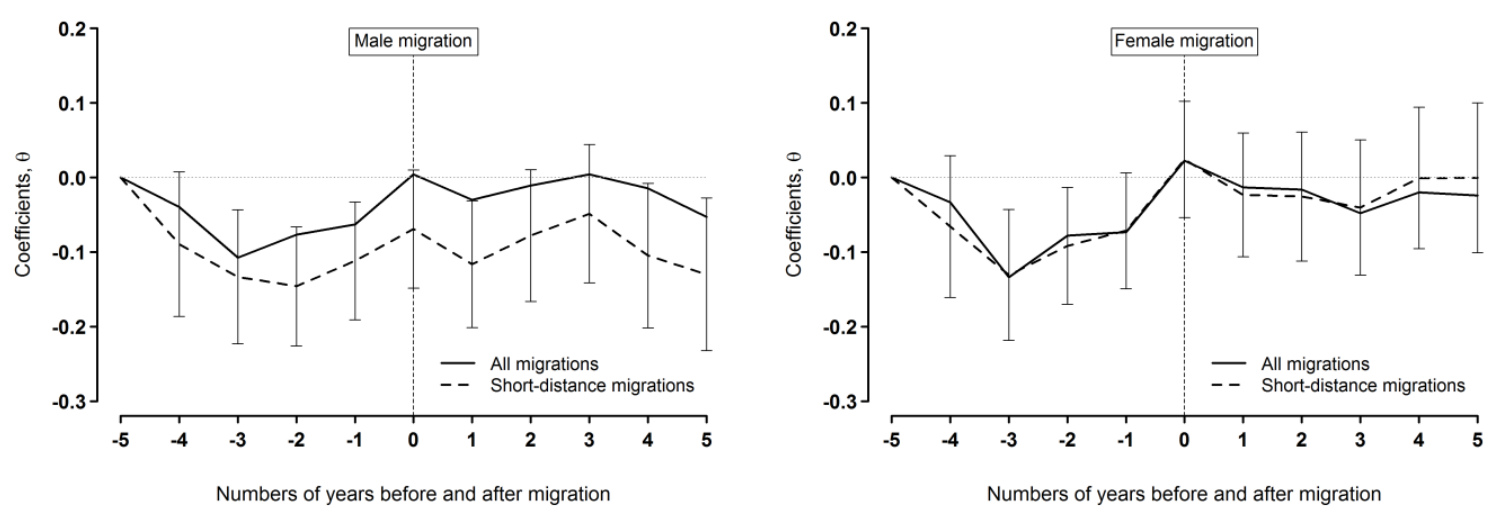

Figure 4 The dynamic effect of short-distance migration on subjective well-being (SWB) of males (left panel) and females (right panel).

Notes: Error bars indicate 95\% confidence intervals for short-distance migrations.

The differences in the effects of personal characteristics on the SWB of people migrating over various distances are limited: short-distance movers are more negatively affected by very poor health. Their happiness is not significantly influenced by being in the widowed category.

Table 4 Fixed-effects model of subjective well-being; the coefficient estimates for the short-distance migrations

\begin{tabular}{lllllll}
\hline Variable $^{\mathrm{a}}$ & \multicolumn{2}{c}{ Total } & \multicolumn{2}{c}{ Males } & \multicolumn{2}{c}{ Females } \\
\hline $\begin{array}{l}\text { No. of years before and after } \\
\text { migration }\end{array}$ & & & & & & \\
-4 & $-0.079^{* * *}$ & $(0.03)^{\mathrm{b}}$ & $-0.089^{*}$ & $(0.049)$ & -0.066 & $(0.049)$ \\
-3 & $-0.136^{* * *}$ & $(0.027)$ & $-0.133^{* * *}$ & $(0.046)$ & $-0.131^{* * * *}$ & $(0.045)$ \\
-2 & $-0.119^{* * *}$ & $(0.024)$ & $-0.146^{* * *}$ & $(0.041)$ & $-0.092^{* * *}$ & $(0.04)$ \\
-1 & $-0.094^{* * *}$ & $(0.028)$ & $-0.112^{* * *}$ & $(0.04)$ & $-0.071^{*}$ & $(0.04)$ \\
0 & -0.023 & $(0.028)$ & $-0.069^{*}$ & $(0.04)$ & 0.024 & $(0.04)$ \\
1 & $-0.069^{* * *}$ & $(0.03)$ & $-0.116^{* * *}$ & $(0.044)$ & -0.023 & $(0.042)$ \\
2 & $-0.053^{*}$ & $(0.032)$ & $-0.078^{*}$ & $(0.045)$ & -0.026 & $(0.044)$ \\
3 & -0.048 & $(0.033)$ & -0.049 & $(0.047)$ & -0.040 & $(0.046)$ \\
4 & -0.050 & $(0.035)$ & $-0.105^{* *}$ & $(0.049)$ & -0.001 & $(0.048)$ \\
5 & -0.060 & $(0.037)$ & $-0.130^{* *}$ & $(0.052)$ & 0.000 & $(0.051)$ \\
Age & $-0.007^{*}$ & $(0.004)$ & $-0.025^{* * *}$ & $(0.006)$ & 0.007 & $(0.006)$ \\
Age squared/100 & 0.000 & $(0.004)$ & $0.022^{* * *}$ & $(0.007)$ & $-0.016^{* * *}$ & $(0.006)$ \\
Marital status & & & & & & \\
Married / living as couple & $0.113^{* * *}$ & $(0.022)$ & $0.127^{* * *}$ & $(0.032)$ & $0.107^{* * * *}$ & $(0.03)$ \\
Widowed & $-0.096^{*}$ & $(0.055)$ & -0.065 & $(0.092)$ & -0.105 & $(0.069)$ \\
Divorced & $-0.072^{*}$ & $(0.037)$ & $-0.110^{* *}$ & $(0.057)$ & -0.045 & $(0.05)$ \\
Separated & $-0.247^{* * *}$ & $(0.04)$ & $-0.311^{* * *}$ & $(0.061)$ & $-0.195^{* * * *}$ & $(0.054)$ \\
Labour market status & & & & & & \\
Unemployed & $-0.337^{* * * *}$ & $(0.027)$ & $-0.376^{* * *}$ & $(0.037)$ & $-0.307^{* * * *}$ & $(0.04)$ \\
Student & $0.115^{* * *}$ & $(0.029)$ & $0.118^{* * *}$ & $(0.045)$ & $0.118^{* * * *}$ & $(0.038)$ \\
Long term sick, disabled & $-0.404^{* * *}$ & $(0.034)$ & $-0.493^{* * *}$ & $(0.049)$ & $-0.333^{* * * *}$ & $(0.047)$ \\
Child born this year & $0.104^{* * *}$ & $(0.02)$ & $0.065^{* *}$ & $(0.029)$ & $0.138^{* * *}$ & $(0.028)$ \\
Number of children & -0.013 & $(0.008)$ & 0.005 & $(0.011)$ & $-0.032^{* * * *}$ & $(0.011)$ \\
Equivalized household income ${ }^{\mathrm{c}}$ & $0.018^{* * * *}$ & $(0.004)$ & $0.025^{* * *}$ & $(0.005)$ & $0.013^{* * *}$ & $(0.005)$ \\
& & & & & &
\end{tabular}


Health status over last 12 months

\begin{tabular}{lllllll} 
Excellent & $0.395^{* * *}$ & $(0.017)$ & $0.365^{* * *}$ & $(0.024)$ & $0.420^{* * *}$ & $(0.023)$ \\
Good & $0.243^{* * *}$ & $(0.013)$ & $0.239^{* * *}$ & $(0.019)$ & $0.244^{* * *}$ & $(0.018)$ \\
Poor & $-0.302^{* * *}$ & $(0.021)$ & $-0.329^{* * *}$ & $(0.033)$ & $-0.289^{* * *}$ & $(0.027)$ \\
Very poor & $-0.742^{* * *}$ & $(0.038)$ & $-0.870^{* * *}$ & $(0.06)$ & $-0.671^{* * *}$ & $(0.048)$ \\
\hline
\end{tabular}

Notes: ${ }^{\mathrm{a}}$ coefficients on wave dummies are not reported; reference categories are never married and fair health; ${ }^{\mathrm{b}}$ standard errors in parentheses; ${ }^{\mathrm{c}}$ in thousand pounds; ${ }^{*}$ significant at $10 \%,{ }^{* *}$ significant at $5 \%,{ }^{* * *}$ significant at $1 \%$.

\section{Discussion and conclusion}

The overall goal of this paper has been to answer the question 'Does migration make you happy?' It does so using contemporary longitudinal data from the BHPS. The use of panel data allowed the analysis to be innovative in examining whether the effects of migration on happiness are transient or permanent. The longitudinal analysis of changes in SWB around the time of migration event presented in this paper provides new insights into implications of migration. Previous studies have mostly focused on the labour market consequences of migration and have neglected other aspects of social life. There are significant SWB changes associated with mobility with the strongest effect in the year of migration. Migrants are happier just after the move than they were just prior to it. A broader temporal perspective reveals, however, that migration is preceded by a decline in SWB. Opportunities available to migrants at new places of residence seem to provide a way out of unhappiness. An alternative hypothesis could be that a decline in happiness before the move reflects the anticipation of the negative effects of moving (in relation to the associated stresses of social networks disruption, leaving familiar surroundings and adjusting to the new environment). The research suggests that a boost in happiness is received through migration bringing people back to their initial level of SWB (Figure 2). Counter to our expectations, long-distance movers are at least as happy as short-distance movers despite the higher social costs that are involved. Moreover, happiness outcomes after migration, as opposed to labour market outcome, do not differ significantly by gender. The happiness of women, who are more often tied migrants, does not seem to be dented even though their career opportunities may become more limited.

In the broader context of SWB our results support the set-point theory of happiness. Individuals shift away from a baseline SWB but they tend to come back to their long-term happiness level. The questionable possibility of lasting improvements in SWB also feeds into the ongoing debate on policy aiming at improving the well-being of societies.

Finally, note that since SWB includes an important temporal dimension, analysing long-run longitudinal data is essential for research to offer meaningful insights into the drivers of and barriers to happiness. Analyses exploring happiness at only one point of time or comparing levels of SWB only before and after the migration event (i.e. at levels reported in only two panel waves before and after migration), are likely to arrive at erroneous conclusions.

Despite its contribution to the understanding of both migration and happiness our study has a few limitations. Although BHPS data enable us to link migrating individuals within couples and to identify lead and tied spouses, the resulting sample size is too small to draw reliable conclusions on long-term happiness patterns. Our findings on tied movers are based, therefore, on comparison between men and women and an underlying assumption that most trailing spouses are women. In addition, the relative importance of various life domains for males and females in migration context needs further investigation. Data-related problems limit also the analysis by migration type. It would be desirable to investigate the happiness 
consequences of migration by its motives. We distinguish short-distance moves from longdistance moves but it is only a crude approximation of migration reasons. Our research rests on the plausible assumption that measures of migration will be exogenous to SWB. This assumption could in theory be explored further through a simultaneous equations approach. However this approach is not trivial and in our experience the relevant set of explanatory variables is not available within the BHPS.

In closing, we would ask and attempt to briefly answer two questions. First, what has this paper contributed to the wider understanding of migration and well-being? Second, what are the implications of this research in relation to exploring the relations between migration and set-point theory?

In answer to the first question, the paper has sought to offer a particularly rigorous analysis of one metric associated with well-being relative to the timing of migration. The originality of the findings, as summarised above, lies in showing that for the individual mover there is relationship with happiness that is a transient one, relating primarily to the years before migration. The returns to migration in terms of happiness appear to be time- specific and not to accumulate after migration, unlike for example potential returns to human capital where one would expect that benefits might accrue to the migrant over many years (in terms for example of increased earnings) as anticipated by neo-classical models of labour migration. Those seeking to theorise migration at the scale of the individual mover need therefore to consider why non-economic returns as measured by indicators of well-being suggest only transient losses and gains. The research findings might therefore be taken to challenge extant theorisations of migration, such as those suggesting that the deeper drivers of migration lie in the social and cultural meanings of mobility rather than in more easily understood economic rewards (Findlay and Stockdale, 2003; Halfacree and Boyle, 1993). A more likely resolution of the differences between the authors' findings and the conceptualisation of migration in the research literature might be found in the suggestion that the research results in this paper relate specifically to short-distance internal migration (involving moves associated with factors like housing needs and life-course adjustments such as divorce (Boyle et al, 2008)), and that different findings might emerge from analysis of well-being before and after international migration. In the latter case different scales of cultural and social disruption seem probable that would be anticipated to be linked to longer run migrant experiences of integration or exclusion. This then emerges as a key research agenda that could usefully be tackled using other datasets.

Turning finally to the wider implications in relation to set-point theory, some might suggest that the findings indicate that internal migration is unlike life events such as marriage, loss of a job or major injury. While they often have a lasting impact on happiness (Clark et al, 2008a; Lucas et al, 2003), internal migration could be interpreted from the results reported in this paper to confirm set point theory views that individuals have stable levels of well-being and that once destabilising events such as migration (or the causes necessitating migration) have been negotiated, then people return to their original level of well-being. An alternative interpretation (and one that we believe our results begin to support as a result of offering detailed insights of temporal variations in SWB) would be to argue that the prospects of mobility as well as the act of engaging in internal migration may be critical means for restoring an individual's level of social well-being, especially following previous stressful events. Indeed one might suggest that without migration the stable sense of well-being anticipated by set point theory might not be regained. Resolving this quandary may well be possible through further research linking motivations for migration to models of well-being in relation to specific life domains. For example, it would be logical to anticipate that features of life satisfaction, such as employment, would be affected very differently as a consequence of migration from domains, such as use of leisure time. More detailed analysis of the relations 
between social well-being and migration, might therefore help not so much to answer the question 'does migration make you happy?', but rather to substantiate the claim that mobility is one of several means by which an individual can regain a stable sense of well-being in the fashion anticipated by set point theory.

\section{References}

Blanchflower D G, Oswald A J, 2008, "Is well-being U-shaped over the life cycle?" Social Science and Medicine 66 1733-1749

Boyle P, Cooke T, Halfacree K H, Smith D, 1999a, "Gender inequality in employment status following family migration in GB and the US: the effect of relative occupational status" International Journal of Sociology and Social Policy 19 109-143

Boyle P, Cooke T, Halfacree K H, Smith D, 1999b, "Integrating GB and US Census Microdata for studying the impact of family migration on partnered women's labour market status" International Journal of Population Geography 5 157-178

Boyle P, Cooke T, Halfacree K H, Smith D, 2001, "A cross-national comparison of the impact of family migration on women's employment status" Demography 38 201-213

Boyle P, Kulu H, Cooke T, Gayle V, Mulder C H, 2008, "Moving and union dissolution" Demography 45 20922

Buck N H, 2000, "Using panel surveys to study migration and residential mobility", in Researching Social and Economic Change: The Uses of Household Panel Studies Ed. D Rose (Routledge, London) pp 250-272

Chiswick B R, 2008, "Are immigrants favorably self-selected? An economic analysis", in Migration Theory: Talking Across Disciplines Eds C D Brettell, J F Hollifield 2nd edition (Routledge, New York) pp 63-82

Clark A E, Diener E, Georgellis Y, Lucas R E, 2008a, "Lags and leads in life satisfaction: a test of the baseline hypothesis" Economic Journal 118 F222-F243

Clark A E, Frijters P, Shields M A, 2008b, "Relative income, happiness, and utility: an explanation for the Easterlin paradox and other puzzles" Journal of Economic Literature 46 95-144

Clark W A V, Huang Y, 2006, "Balancing move and work: women's labour market exits and entries after family migration" Population, Space and Place 12 31-44

Cooke T J, 2003, "Family migration and the relative earnings of husbands and wives" Annals of the Association of American Geographers 93 338-349

Cooke T J, 2008, "Gender role beliefs and family migration" Population, Space and Place 14 163-175

Cooke T J, Bailey A J, 1999, "The effect of family migration, migration history and self-selection on married women's labour market achievement", in Migration and Gender in the Developed World Eds $\mathrm{P}$ Boyle, K Halfacree (Routledge, London) pp 102-113

Couch K A, 2001, "Earnings losses and unemployment of displaced workers in Germany" Industrial and Labor Relations Review 54 559-572

Couch K A, Jolly N A, Placzek D W, 2011, "Earnings losses of displaced workers and the business cycle: an analysis with administrative data" Economics Letters 111 16-19

Couch K A, Placzek D W, 2010, "Earnings losses of displaced workers revisited" American Economic Review $100572-589$

Coulter R, van Ham M, 2012, "Partner disagreement on moving decisions and the subsequent moving behaviour of couples" Population Space and Place (forthcoming)

Cummins R A, 1996, "The domains of life satisfaction: An attempt to order chaos" Social Indicators Research 38 303-328

Diener E, 2009, "Subjective well-being", in The Science of Well-Being: The Collected Works of Ed Diener Ed. E Diener (Springer, The Netherlands) pp 11-58

Diener E, Diener C, 1996, "Most people are happy" Psychological Science 7 181-185

Diener E, Scollon C N, Lucas R E, 2003, "The evolving concept of subjective well-being: the multifaceted nature of happiness" Advances in Cell Aging and Gerontology 15 187-219

Diener E, Seligman M E P, 2004, "Beyond money: toward an economy of well-being" Psychological Science in the Public Interest 5 1-31

Dolan P, Peasgood T, White M, 2008, "Do we really know what makes us happy? A review of the economic literature on the factors associated with subjective well-being" Journal of Economic Psychology 29 94-122

Easterlin R A, 1995, "Will raising the incomes of all increase the happiness of all?" Journal of Economic Behavior and Organization 27 35-47

Easterlin R A, 2001, "Income and happiness: towards a unified theory" The Economic Journal 111 465-484 
Easterlin R A, 2006a, "Building a better theory of well-being", in Economics and Happiness: Framing the Analysis Eds L Bruni, P Porta (Oxford University Press, Oxford)

Easterlin R A, 2006b, "Life cycle happiness and its sources. Intersections of psychology, economics, and demography" Journal of Economic Psychology 27 463-482

Easterlin R A, McVey L A, Switek M, Sawangfa O, Zweig J S, 2010, "The happiness-income paradox revisited" Proceedings of the National Academy of Sciences 107 22463-22468

Ferrer-i-Carbonell A, 2005, "Income and well-being: An empirical analysis of the comparison income effect" Journal of Public Economics 89 997-1019

Ferrer-i-Carbonell A, Frijters P, 2004, "How important is methodology for the estimates of the determinants of happiness?" Economic Journal 114 641-659

Findlay A M, Stockdale A, 2003, "The temporal and social embeddedness of migration: a methodological exploration using biographical analysis" Geography Research Forum 23 4-29

Fischer P A, Malmberg G, 2001, "Settled people don't move: on life course and (im-)mobility in Sweden" International Journal of Population Geography 7 357-371

Frijters P, Johnston D W, Shields M A, 2011, "Life satisfaction dynamics with quarterly life event data" Scandinavian Journal of Economics 113 190-211

Halfacree K H, 1995, "Household migration and the structuration of patriarchy: evidence from the USA" Progress in Human Geography 19 159-182

Halfacree K H, Boyle P, 1993, "The challenge facing migration research: the case for a biographical approach" Progress in Human Geography 17 333-348

Headey B, 2010, "The set point theory of well-being has serious flaws: on the eve of a scientific revolution?" Social Indicators Research 97 7-21

Jacobson L S, LaLonde R J, 1993, "Earnings losses of displaced workers" American Economic Review 83685

Kahneman D, Krueger A B, Schkade D, Schwarz N, Stone A A, 2006, "Would you be happier if you were richer? A focusing illusion" Science 312 1908-1910

LeClere F B, McLaughlin D K, 1997, "Family migration and changes in women's earnings: a decomposition analysis" Population Research and Policy Review 16 315-335

Lichter D T, 1983, "Socioeconomic returns to migration among married women" Social Forces 62 487-503

Lucas R E, Clark A E, Georgellis Y, Diener E, 2003, "Reexamining adaptation and the set point model of happiness: reactions to changes in marital status" Journal of Personality and Social Psychology 84 527-539

Lucas R E, Clark A E, Georgellis Y, Diener E, 2004, "Unemployment alters the set point for life satisfaction" Psychological Science 15 8-13

Magdol L, 2002, "Is moving gendered? The effects of residential mobility on the psychological well-being of men and women" Sex Roles 47 553-560

McAdams K K, Lucas R E, Donnellan M B, 2011, "The role of domain satisfaction in explaining the paradoxical association between life satisfaction and age" Social Indicators Research (forthcoming)

McCollum A, 1990 The Trauma of Moving: Psychological Issues for Women (Sage Publications, London)

Mincer J, 1978, "Family migration decisions" The Journal of Political Economy 86 749-773

Morrison D R, Lichter D T, 1988, "Family migration and female employment: the problem of underemployment among migrant married women" Journal of Marriage and Family 50 161-172

Mulder C H, Cooke T J, 2009, "Family ties and residential locations" Population, Space and Place 15 299-304

Pavot W, Diener E, in press, "Happiness experienced: The science of subjective well-being", in Oxford Handbook of Happiness Eds I Boniwell, S David (Oxford University Press, Oxford)

Prime Minister's Office, 25 November 2010, "PM speech on wellbeing", http://www.number10.gov.uk/news/speeches-and-transcripts/2010/11/pm-speech-on-well-being-57569

Rabe B, Taylor M, 2010, "Residential mobility, quality of neighbourhood and life course events" Journal of the Royal Statistical Society: Series A (Statistics in Society) 173 531-555

Schimmack U, 2008, "The structure of subjective well-being", in The Science of Subjective Well-Being Eds R Larsen, M Eid (Guilford Press, New York) pp 97-123

Shihadeh E S, 1991, "The prevalence of husband-centered migration: employment consequences for married mothers" Journal of Marriage and Family 53 432-444

Stiglitz J, Sen A, Fitoussi J, 2009, "Report by the Commission on the Measurement of Economic Performance and Social Progress", www.stiglitz-sen-fitoussi.fr

Stratton A, 2010, "David Cameron aims to make happiness the new GDP" The Guardian 15 November, page 14, http://www.guardian.co.uk/politics/2010/nov/14/david-cameron-wellbeing-inquiry

Stutzer A, 2004, "The role of income aspirations in individual happiness" Journal of Economic Behavior \& Organization 54 89-109

van Praag B M S, Frijters P, Ferrer-i-Carbonell A, 2003, "The anatomy of subjective well-being" Journal of Economic Behavior \& Organization $5129-49$

White R, 2010, "Long-run wage and earnings losses of displaced workers" Applied Economics 42 1845-1856 